\title{
Urokinase Has Direct Catalytic Activity against Fibrinogen and Renders It Less Clottable by Thrombin
}

\author{
Jeffrey I. Weitz and Beverly Leslie \\ Department of Medicine, McMaster University and Hamilton Civic Hospitals Research Centre, Hamilton, Ontario L8V IC3, Canada
}

\begin{abstract}
Recently, we demonstrated that tissue plasminogen activator directly releases fibrinopeptides A and B (FPA and FPB) from fibrinogen. The purpose of this study was to determine whether urokinase has similar activity. Incubation of urokinase with fibrinogen or heparinized plasma results in concentration-dependent FPB release unaccompanied by FPA cleavage. For equivalent amidolytic activity, high molecular weight urokinase releases twofold more FPB than the low molecular weight species. In contrast, prourokinase does not release FPB until activated to urokinase. Contaminating thrombin or plasmin is not responsible for urokinase-mediated FPB release because this activity is unaccompanied by FPA or B $\beta 1-42$ cleavage, and is unaffected by heparin, hirudin, a monospecific antibody against thrombin, aprotinin, or $\alpha_{2}$-antiplasmin. FPB release reflects a direct action of urokinase on fibrinogen because release is completely inhibited by a monospecific antibody against the enzyme. Further, urokinase releases FPB from the FPB-containing substrate $B \beta 1-42$, thus confirming its specificity for the B $\beta 14$ (Arg)-B $\beta 15$ (Gly) bond. In addition to FPB release, SDS-PAGE analysis of the time course of urokinasemediated fibrinogenolysis indicates progressive proteolysis of both the $A \alpha$ - and $B \beta$-chains of fibrinogen that occurs after FPB release is completed. As a consequence of urokinase-mediated fibrinogenolysis, there is progressive prolongation of the thrombin clotting time. These studies indicate that urokinase has direct catalytic activity against fibrinogen. By releasing FPB, a potent chemoattractant, and by rendering fibrinogen less clottable by thrombin, urokinase may participate in processes extending beyond fibrinolysis. (J. Clin. Invest. 1990. 86:203-212.) Key words: fibrinogenolysis • fibrinopeptide $B$ • urokinase-type plasminogen activator
\end{abstract}

\section{Introduction}

The plasminogen activators catalyze the conversion of plasminogen into the enzyme plasmin. Two distinct plasminogen activators have been identified: urokinase-type plasminogen

This study was presented in part at the 61 st Scientific Sessions of the American Heart Association, Washington, DC, and published in abstract form (1988. Circulation. 78:2035a).

Address reprint requests to Dr. Weitz, Henderson General Hospital, 711 Concession Street, Hamilton, Ontario L8V 1C3, Canada.

Received for publication 4 August 1989 and in revised form 20 December 1989.

J. Clin. Invest.

(C) The American Society for Clinical Investigation, Inc.

0021-9738/90/07/0203/10 \$2.00

Volume 86, July 1990, 203-212 activator (u-PA) ${ }^{1}$ and tissue-type plasminogen activator (t-PA). u-PA and t-PA are serine proteinases that have similar structural and catalytic properties. There are important functional differences however, between the two enzymes. Whereas t-PA binds to fibrin, an interaction that dramatically increases its catalytic activity against clot-bound plasminogen $(1,2)$, u-PA binds to specific receptors found on the plasma membrane of a variety of benign and malignant cell types (3-11). The activity of u-PA is thus localized to the cell surface while that of t-PA is mainly directed against fibrin. Accordingly, the two plasminogen activators may have distinct physiologic roles.

Both u-PA and t-PA are synthesized as single-chain polypeptides that are readily hydrolyzed into two-chain species held together by single disulfide bonds (12-14). Although single-chain t-PA is enzymatically active (15), single-chain u-PA or prourokinase is a zymogen with little or no intrinsic enzymatic activity (16-18). Cleavage of the Lys 158-Ile 159 bond of prourokinase generates an active two-chain molecule $(54,000 \mathrm{~mol} \mathrm{wt})$ referred to as high molecular weight (HMW) urokinase (13). Subsequent hydrolysis of the Lys 135-Lys 136 bond on the amino-terminal region of HMW urokinase yields another enzymatically active, two-chain form of the enzyme, known as low molecular weight (LMW) urokinase (19). This species $(33,000 \mathrm{~mol} \mathrm{wt})$ is the predominant form of urokinase found in commercial preparations of enzyme.

The traditional view is that the plasminogen activators effect fibrinogen proteolysis by activating plasminogen to plasmin. Recently however, we have demonstrated that t-PA can produce limited degradation of fibrinogen under plasminogen-free conditions (20). Thus, t-PA has a thrombinlike effect on fibrinogen and releases fibrinopeptides A and B (FPA, FPB). The purpose of this study was to determine whether u-PA also has direct catalytic activity against fibrinogen.

\section{Methods}

Reagents. Human $\alpha$-thrombin (sp act, $2,850 \mathrm{U} / \mathrm{mg}$ ) was generously provided by Dr. J. Fenton II, New York State Department of Health, Albany, NY. Predominantly single-chain recombinant t-PA (lot K9051 A6) was from Genentech, Inc., South San Francisco, CA; streptokinase was obtained from Hoechst Pharmaceuticals, Inc., Summerville, NJ. Human plasmin (sp act 15 casein units $[\mathrm{CU}] / \mathrm{mg}$ ) and the synthetic substrate for urokinase, L-pyroglutamyl-glycyl-L-arginine-pnitroanilide (S2444), were obtained from Kabi Vitrum, Stockholm, Sweden. Human $\alpha_{2}$-antiplasmin, plasminogen with an amino-termi-

1. Abbreviations used in this paper: FPA, fibrinopeptide A (A $\alpha 1-16)$; FPB, fibrinopeptide B (B/1-14); HMW, high molecular weight; LMW, low molecular weight; t-PA, tissue-type plasminogen activator; u-PA, urokinase-type plasminogen activator. 
nal Glu residue (Glu-plasminogen), and a monospecific polyclonal goat IgG against human urokinase were from American Diagnostica Inc., New York, NY. A monospecific polyclonal sheep IgG against human thrombin was provided by Dr. F. Ofosu, McMaster University Medical Centre, Hamilton, Ont. Previous studies with this antibody (20) demonstrated that at a concentration of $5 \mu \mathrm{g} / \mathrm{ml}$ it inhibited $>98 \%$ of the FPA and FPB released from fibrinogen $(0.6 \mathrm{mg} / \mathrm{ml})$ by human $\alpha$-thrombin (at concentrations in a range of $0.01-0.2 \mathrm{U} / \mathrm{ml}$ ). Hirudin and PMSF were purchased from Sigma Chemical Co., St. Louis, MO; aprotinin was from FBA Pharmaceuticals, New York. The FPB-containing fragment, $\mathrm{B} \beta 1-42$, was isolated from a limited plasmin digest of fibrinogen using reverse-phase high-performance liquid chromatography techniques described elsewhere (21). Synthetic human FPA and FPB were purchased from Bachem, Inc., Torrance, CA.

Urokinase preparations. Prourokinase and LMW urokinase were generously provided by Dr. J. Henkin, Abbott Laboratories, North Chicago, IL. The urokinase preparations were further purified by chromatography on benzamidine-CH Sepharose 4B (Pharmacia Fine Chemicals, Piscataway, NJ). In this way, contaminating two-chain urokinase was removed from the prourokinase preparation, while enzymatically active LMW urokinase absorbed to the benzamidine- $\mathrm{CH}$ Sepharose 4B was separated from inactive enzyme after elution with $0.4 \mathrm{M} \mathrm{NaCl}$ buffered with $0.1 \mathrm{M}$ ammonium acetate to $\mathrm{pH} 4.0$ (22).

HMW urokinase was generated by incubating prourokinase with immobilized plasmin. Plasminogen was first coupled to cyanogen bromide (CNBr)-activated Sepharose 4B (Pharmacia Fine Chemicals) at a concentration of $4 \mathrm{mg} / \mathrm{ml}$. The immobilized plasminogen $(2 \mathrm{ml}$ of a $50 \%$ suspension) was then converted to plasmin by incubation with $20 \mu \mathrm{g}$ of LMW urokinase for $30 \mathrm{~min}$ at $37^{\circ} \mathrm{C}$. After removing the urokinase by centrifugation and repeated washing, immobilized plas$\min (1 \mathrm{ml}$ of a $50 \%$ suspension) was mixed with $2.5 \mathrm{mg}$ of prourokinase and agitated for $40 \mathrm{~min}$ at $4^{\circ} \mathrm{C}$. After centrifugation, the supernatant was further purified on benzamidine-CH Sepharose 4B as described above. Electrophoresis of $10 \mu \mathrm{g}$ of reduced sample on a $10 \%$ polyacrylamide gel revealed over $98 \%$ conversion of prourokinase to two-chain HMW urokinase.

The activity of the three urokinase preparations was determined by comparing their hydrolysis of L-pyroglutamyl-glycyl-L-arginine-p-nitroanilide (S2444) with that produced by known concentrations of the first International Reference Preparation for Human Urokinase (66/46) obtained from Dr. P. J. Gaffney, National Institute for Biological Standards and Control, Potters Bar, UK. The amidolytic activity of prourokinase was measured before and after its conversion to twochain urokinase with plasmin. The activities of the prourokinase, HMW urokinase, and LMW urokinase preparations were 63,329 , 22,114 , and $116,394 \mathrm{IU} / \mathrm{mg}$, respectively.

Purification of fibrinogen. Human fibrinogen (grade L, Kabi Vitrum) was rendered plasminogen-free by lysine Sepharose 4B affinity chromatography (23) in the presence of aprotinin (100 kallikrein inhibitory units $[\mathrm{KIU}] / \mathrm{ml})$. The fibrinogen was then concentrated by precipitation at $23^{\circ} \mathrm{C}$ with $25 \%$ saturated ammonium sulfate, $\mathrm{pH}$ 7.4. After the precipitated material was resuspended in $5 \mathrm{mM}$ trisodium citrate, $\mathrm{pH} 7.4$, the precipitation and resuspension procedure was repeated an additional two times. The fibrinogen was then dialyzed against $5 \mathrm{mM}$ trisodium citrate for $48 \mathrm{~h}$ at $4^{\circ} \mathrm{C}$. After removal of cold-insoluble material by centrifugation, the fibrinogen was dialyzed against $0.1 \mathrm{M} \mathrm{NaCl}$ buffered to $\mathrm{pH} 7.4$ with $0.05 \mathrm{M}$ Tris- $\mathrm{HCl}$ (TBS) for $24 \mathrm{~h}$ at $4^{\circ} \mathrm{C}$, and stored in aliquots at $-70^{\circ} \mathrm{C}$.

The clottability of the purified material was $96 \%$. The absence of plasminogen was confirmed by incubating the fibrinogen for $48 \mathrm{~h}$ at $37^{\circ} \mathrm{C}$ with streptokinase ( $3 \mathrm{U} / \mathrm{mg}$ fibrinogen) or recombinant t-PA ( 2 $\mu \mathrm{g} / \mathrm{mg}$ fibrinogen). Electrophoresis of $50 \mu \mathrm{g}$ of sample (under reducing and nonreducing conditions) on a $7.5 \%$ polyacrylamide gel revealed no evidence of degradation. Further, the absence of detectable B $\beta 1-42$ release during the 48-h incubation period indicates that neither streptokinase nor recombinant $t$-PA treatment generates plasmin.

Radioimmunoassays. FPA was assayed as previously described (24) using antiserum R2 which is specific for this peptide $(20,25,26)$.
FPB was quantified as described elsewhere (27) using antiserum R28. In plasma, however, there is rapid loss of FPB immunoreactivity when measured with R28 (28) as a result of carboxypeptidase-mediated cleavage of $\operatorname{Arg}(B \beta 14)$. Accordingly, FPB cannot be measured directly but can be quantified by employing antiserum $R 30$ to measure plasma levels of desarginine FPB after $(a)$ selective removal of crossreacting FPB-containing fragments by bentonite adsorption, and $(b)$ complete conversion of FPB in the sample to desarginine FPB by incubation with carboxypeptidase $B$ as described in detail elsewhere (29). The plasmin-derived fibrinogen fragment $B \beta 1-42$ was assayed as previously described using a specific antiserum that does not crossreact with FPB or $\mathrm{B} \beta 15-42(30)$.

Cleavage of fibrinogen by urokinase. Fibrinogen, suspended at a concentration of $1 \mathrm{mg} / \mathrm{ml}$ in TBS, was incubated with LMW urokinase (at concentrations ranging from $6.5 \mathrm{nM}$ to $2.6 \mu \mathrm{M}$ which correspond to $25-10,000 \mathrm{IU} / \mathrm{ml}$ ), HMW urokinase (at concentrations ranging from $7.3 \mathrm{nM}$ to $0.3 \mu \mathrm{M}$; i.e., $25-1,000 \mathrm{IU} / \mathrm{ml}$ ), or prourokinase (at concentrations ranging from $20.9 \mathrm{nM}$ to $0.8 \mu \mathrm{M}$; i.e., $25-1,000 \mathrm{IU} / \mathrm{ml}$ ) for $4 \mathrm{~h}$ at $37^{\circ} \mathrm{C}$. At intervals, $200-\mu \mathrm{l}$ aliquots were removed, and the reaction was terminated by the addition PMSF ( $5 \mathrm{mM}$, final concentration). The unreacted fibrinogen in half of the sample was then precipitated by the addition of $300 \mu \mathrm{l}$ of chilled ethanol followed by centrifugation at $15,000 \mathrm{~g}$ for $5 \mathrm{~min}$. The ethanol supernatants were evaporated to dryness in a Speed-Vac concentrator (Savant Instruments, Inc., Farmingdale, NY), reconstituted to original volume with distilled water, and assayed for FPA and FPB immunoreactivity. The remaining 100 $\mu \mathrm{l}$ was dissolved in an equal volume of $60 \mathrm{mM}$ Tris- $\mathrm{HCl}$ containing $2 \%$ SDS, $5 \%$ glycerol, and $0.001 \%$ bromophenol blue, heated to $100^{\circ} \mathrm{C}$ for $5 \mathrm{~min}$, and then stored at $-70^{\circ} \mathrm{C}$ before analysis by SDS polyacrylamide gel electrophoresis (PAGE).

SDS-PAGE analysis of urokinase-mediated fibrinogenolysis. The time course of urokinase proteolysis of fibrinogen also was monitored by SDS-PAGE. Samples were heated to $100^{\circ} \mathrm{C}$ for $5 \mathrm{~min}$ in the presence or absence of 5\% 2-mercaptoethanol, and then $8 \mu \mathrm{l}$ was applied to each lane of a $10 \%$ polyacrylamide slab gel (3.9\% stacking gel). Electrophoresis was performed using a modified Laemmli discontinuous buffer system (31), and the gels were then fixed in 10\% methanol/17\% acetic acid, and stained with Coomassie Blue.

High-performance liquid chromatography (HPLC) analysis of urokinase-mediated fibrinogenolysis. Urokinase-mediated proteolysis of fibrinogen also was monitored using reverse-phase HPLC. Fibrinogen was suspended in TBS at a concentration of $1 \mathrm{mg} / \mathrm{ml}$. The fibrinogen was digested with $\mathrm{LMW}$ urokinase $(0.5 \mu \mathrm{M})$ for $60 \mathrm{~min}$ at $37^{\circ} \mathrm{C}$. At various times, 200- $\mu$ l aliquots of the digestion mixture were removed and proteolysis was stopped by the addition of PMSF (final concentration, $5 \mathrm{mM}$ ). Undigested fibrinogen was then removed by passage of the samples over Sep-Pak C18 cartridges (Waters Associates, Milford, MA). Adsorbed peptides were eluted with $3 \mathrm{ml}$ of $50 \%$ acetonitrile, evaporated to dryness, and dissolved in $0.1 \%$ trifluoroacetic acid before HPLC analysis.

Analytic HPLC was performed using a liquid chromatograph (Beckman Instruments, Inc., Palo Alto, CA) equipped with a model 421 A controller, two model 114 solvent delivery systems, an automatic injector (model 504, Beckman Instruments, Inc.) and a data module (model CR1A, Shimadzu Scientific Instruments, Inc., Columbia, MD) plotter-integrator. Peptides were monitored using a fixed wave length detector (model 160, Beckman Instruments, Inc.) with a 214-nm filter. The column employed was an Ultrasphere ODS C18 (4.6 $\mathrm{mm}$ i.d., Beckman Instruments, Inc.). Solvents used in the chromatography included $0.1 \%$ trifluoroacetic acid (buffer $\mathrm{A}$ ) and $0.1 \%$ trifluoroacetic acid containing $50 \%$ acetonitrile (buffer B). Peptide samples were eluted from the column using gradients containing various concentrations of buffer $B$ in the mobile phase. 1-ml fractions were collected, evaporated to dryness, and then assayed for FPA and FPB immunoreactivity. The immunoreactive fractions were pooled, further purified using reverse-phase HPLC, and then subjected to amino acid analysis.

Amino acid analysis. Samples were hydrolyzed in $6 \mathrm{~N} \mathrm{HCl}$ containing $0.3 \%$ phenol in vacuo for $2 \mathrm{~h}$ at $150^{\circ} \mathrm{C}$ and then analyzed using 
standard techniques on an amino acid analyzer (model 6300, Beckman Instruments, Inc.) (32).

Cleavage of $B \beta 1-42$ by urokinase. Experiments were performed at $37^{\circ} \mathrm{C}$ in TBS. The FPB-containing peptide B $\beta 1-42$, diluted in TBS to a final concentration of $1 \mathrm{mg} / \mathrm{ml}$, was incubated with $5 \mu \mathrm{l}$ of LMW urokinase $(1.5 \mu \mathrm{M})$ for $2 \mathrm{~h}$ at $37^{\circ} \mathrm{C}$. In a control experiment, the B $\beta 1-42$ was incubated with buffer in place of enzyme. At intervals, aliquots were removed, the reaction was terminated by the addition of PMSF (final concentration, $5 \mathrm{mM}$ ), and the samples were then assayed for $B \beta 1-42$ and FPB.

Urokinase-mediated proteolysis of $\mathrm{B} \beta 1-42$ also was monitored using reverse-phase HPLC. $20 \mu \mathrm{g}$ of $\mathrm{B} \beta 1-42$ suspended in $200 \mu \mathrm{l}$ of TBS was incubated with LMW urokinase $(2 \mu \mathrm{g})$ or with an equivalent volume of buffer for $2 \mathrm{~h}$ at $37^{\circ} \mathrm{C}$. At the end of the incubation period, proteolysis was stopped by passage of the sample over a Sep-Pak C18 cartridge. Adsorbed peptides were eluted with $3 \mathrm{ml}$ of $50 \%$ acetonitrile, evaporated to dryness, dissolved in $0.1 \%$ trifluoroacetic acid, and then subjected to HPLC analysis using native B $\beta 1-42$, B $\beta 15-42$, and FPB as internal standards. $1-\mathrm{ml}$ fractions were collected and assayed for B $\beta 1-42$ and FPB.

Estimation of the kinetic parameters for urokinase-mediated cleav-

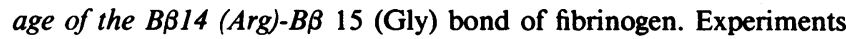
were performed in TBS at $37^{\circ} \mathrm{C} .1-\mathrm{ml}$ aliquots of fibrinogen (at concentrations in a range of 0.74-14.7 $\mu \mathrm{M}$ ) were incubated with 500 $\mathrm{IU} / \mathrm{ml}(130 \mathrm{nM}) \mathrm{LMW}$ urokinase for $120 \mathrm{~min}$. At intervals, 100- $\mathrm{l}$ aliquots were removed, the reaction was terminated by the addition of PMSF ( $5 \mathrm{mM}$, final concentration), and the fibrinogen was precipitated by the addition of $300 \mu \mathrm{l}$ of chilled ethanol followed by centrifugation at $15,000 \mathrm{~g}$ for $5 \mathrm{~min}$. The ethanol supernatants were then evaporated to dryness, reconstituted to original volume with distilled ethanol, and assayed for FPB.

At each fibrinogen concentration, the velocity of FPB release was calculated by measuring the appearance of FPB immunoreactivity during the initial $\mathbf{4 0} \mathrm{min}$ of the reaction. Release was linear during this interval, and $<10 \%$ of the substrate was consumed.

Thrombin clotting times of urokinase-treated fibrinogen. Fibrinogen, suspended in TBS at a concentration of $1.2 \mathrm{mg} / \mathrm{ml}$, was incubated with LMW urokinase (at concentrations in a range of $0.1-0.3 \mu \mathrm{M}$ ) for $2 \mathrm{~h}$ at $37^{\circ} \mathrm{C}$. In control experiments, the fibrinogen was incubated with buffer in place of enzyme. At intervals, 250- $\mu$ l aliquots were taken and the urokinase was removed by incubation with benzamidine-Sepharose ( $100 \mu \mathrm{l}$ of a $50 \%$ suspension) for $20 \mathrm{~min}$ at room temperature with constant agitation. After centrifugation at $15,000 \mathrm{~g}$ for $5 \mathrm{~min}$, the supernatants were removed and the fibrinogen concentration was determined by measuring both the protein concentration according to the method of Lowry et al. (33), and the absorbance at $280 \mathrm{~nm}$ using an extinction coefficient of 1.55 . After adjusting the concentration of fibrinogen to $0.5 \mathrm{mg} / \mathrm{ml}$, thrombin clotting times were determined using bovine thrombin (Parke-Davis and Co., Detroit, $\mathrm{MI}$ ) at $10 \mathrm{U} / \mathrm{ml}$ in TBS.

Thrombin-mediated fibrinopeptide release from urokinase-treated fibrinogen. Experiments were performed at $37^{\circ} \mathrm{C}$ in TBS. $1-\mathrm{ml}$ samples of fibrinogen $(1.2 \mathrm{mg} / \mathrm{ml})$ were incubated with LMW urokinase (at concentrations in a range of $0.1-0.3 \mu \mathrm{M}$ ) for $2 \mathrm{~h}$. Control samples were incubated with buffer in place of enzyme. The urokinase was then removed by incubation with benzamidine-Sepharose $(400 \mu \mathrm{l}$ of a $50 \%$ suspension) for $20 \mathrm{~min}$ at room temperature with constant agitation. After centrifugation at $5,000 \mathrm{~g}$ for $5 \mathrm{~min}$, the supernatants were extensively dialyzed against TBS to remove released peptide fragments, and the fibrinogen concentrations adjusted to $0.46 \mathrm{mg} / \mathrm{ml}$.

Control and urokinase-treated fibrinogen preparations were incubated with $0.02 \mathrm{U} / \mathrm{ml}$ human $\alpha$-thrombin for $2 \mathrm{~h}$ at $37^{\circ} \mathrm{C}$. At intervals, $100-\mu 1$ aliquots were removed, the reaction was terminated by the addition of $0.1 \mathrm{U}$ of hirudin, and unreacted fibrinogen was precipitated with $300 \mu \mathrm{l}$ of chilled ethanol followed by centrifugation at $15,000 \mathrm{~g}$ for $5 \mathrm{~min}$. The ethanol supernatants were then evaporated to dryness, reconstituted to original volume with distilled water, and assayed for FPA and FPB.
Urokinase-mediated generation of FPB and B B1-42 in plasma. Using a 21-gauge butterfly needle, blood was collected from an antecubital vein of healthy volunteers into $10-\mathrm{ml}$ vacutainer tubes prefilled with $143 \mathrm{U}$ of sodium heparin (Becton, Dickinson \& Co., Toronto, Ont.). The red cells were sedimented by centrifugation at $1,700 \mathrm{~g}$ for 15 min at $4^{\circ} \mathrm{C}$ and the plasma was harvested. LMW urokinase (at concentrations in a range of $25-250 \mathrm{nM}$ ) was incubated with $250-\mu 1$ aliquots of heparinized plasma for $60 \mathrm{~min}$ at $37^{\circ} \mathrm{C}$ in the absence or presence of aprotinin $(500 \mathrm{KJU} / \mathrm{ml})$ or $\alpha_{2}$-antiplasmin $(1 \mu \mathrm{M}$, final concentration). The reaction was then terminated by the addition of PMSF ( $5 \mathrm{mM}$, final concentration), and the fibrinogen was precipitated by the addition of $750 \mu$ l of chilled ethanol followed by centrifugation at $15,000 \mathrm{~g}$ for $5 \mathrm{~min}$. The ethanol supernatants were then evaporated to dryness in a Speed-Vac concentrator, reconstituted to original volume with water, and assayed for desarginine FPB and B $\beta 1-42$.

\section{Results}

Urokinase-mediated FPB release from fibrinogen. The incubation of LMW urokinase with fibrinogen results in time and dose-dependent FPB release unaccompanied by FPA cleavage (Fig. 1). This is in direct contrast to thrombin $(27,34)$ or t-PA (20) which releases both fibrinopeptides. By plotting the amount of FPB released from fibrinogen after $60 \mathrm{~min}$ of incubation as a function of the urokinase concentration, a doseresponse curve was constructed (Fig. 2). At concentrations of 1 $\mu \mathrm{M}$ or higher, urokinase produces quantitative release of FPB ( $2 \mathrm{~mol} / \mathrm{mol}$ fibrinogen), and no FPA cleavage.

Comparison of the FPB-releasing activity of prourokinase, $H M W$ urokinase, and $L M W$ urokinase. The FPB-releasing activity of prourokinase and HMW urokinase was compared with that of LMW urokinase (Fig. 3). For equivalent amidoly-

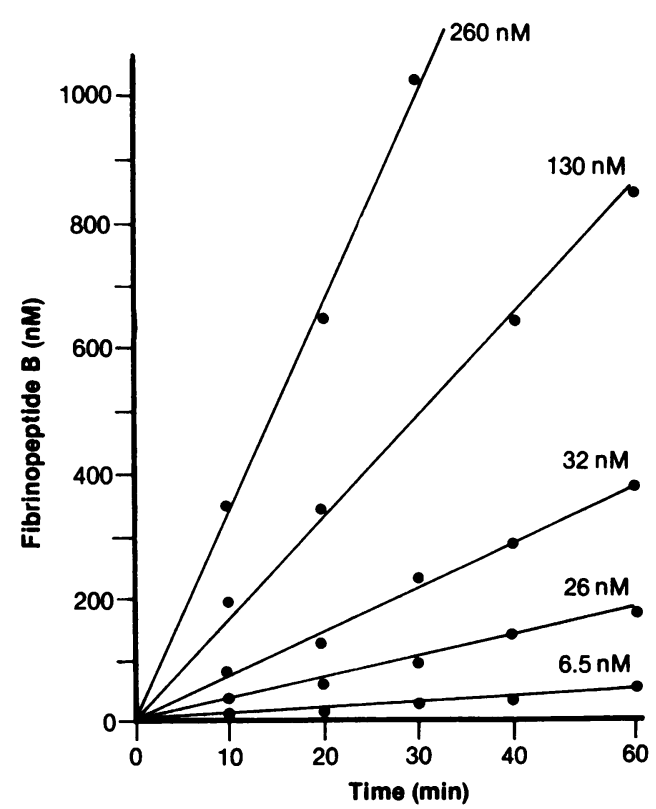

Figure 1. Time course of urokinase-mediated FPB release from fibrinogen. Fibrinogen $(1.8 \mu \mathrm{M})$ was incubated with varying concentrations of urokinase for $60 \mathrm{~min}$ at $37^{\circ} \mathrm{C}$. At the times indicated, aliquots were removed, unreacted fibrinogen was precipitated with ethanol, and the ethanol supernatants were assayed for FPB. The results shown are the mean of two separate experiments. 


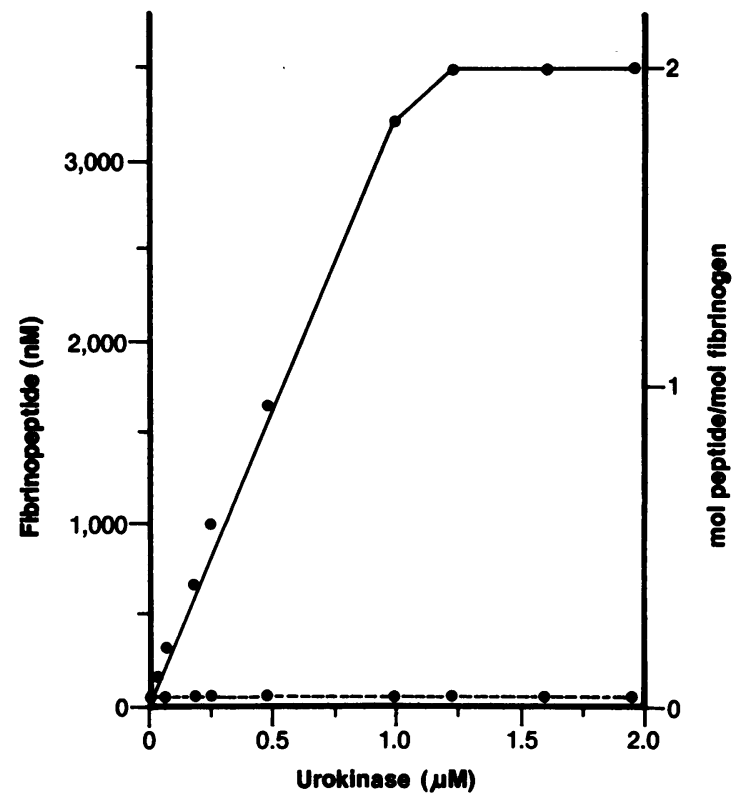

Figure 2. Urokinase-mediated fibrinopeptide release from fibrinogen. Aliquots of fibrinogen $(1.8 \mu \mathrm{M})$ were incubated with increasing concentrations of urokinase for $60 \mathrm{~min}$ at $37^{\circ} \mathrm{C}$. The reaction was terminated, unreacted fibrinogen was precipitated with ethanol, and the ethanol supernatants were then assayed for FPA (dashed line) and FPB (solid line). The results shown represent the mean of three separate experiments.

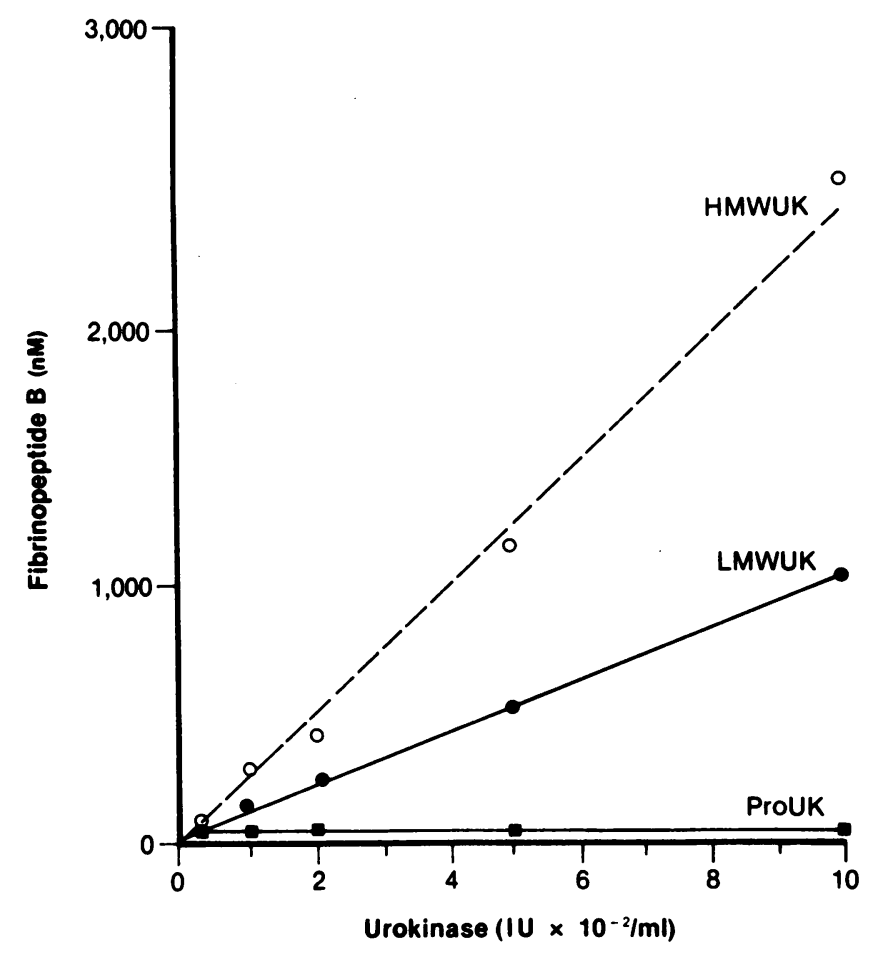

Figure 3. Comparison of the FPB releasing activity of prourokinase (ProUK), HMW urokinase (HMWUK), and LMW urokinase $(L M W U K)$. Fibrinogen $(1.8 \mu \mathrm{M})$ was incubated with prourokinase, HMW urokinase, or LMW urokinase for $60 \mathrm{~min}$ at $37^{\circ} \mathrm{C}$. The reactions were terminated, unreacted fibrinogen was precipitated with ethanol, and the ethanol supernatants were then assayed for FPB. The results illustrated represent the mean of three separate experiments. tic activity, HMW urokinase releases approximately twofold more FPB than does the LMW form. In contrast, prourokinase does not release FPB. When the prourokinase is converted to urokinase however, there is FPB release similar in amount to that produced by two-chain urokinase (data not shown). These findings are consistent with the concept that prourokinase is a zymogen and lacks intrinsic enzymatic activity (16-18).

HPLC separation of the products of urokinase-mediated fibrinogenolysis. To confirm that the increase in FPB immunoreactivity after urokinase incubation with fibrinogen represents release of the free peptide, the products of urokinase-mediated fibrinogenolysis were separated by reverse-phase HPLC using synthetic FPA and FPB as internal standards. 1-ml fractions were collected and assayed for FPA and FPB immunoreactivity (Fig. 4). A single FPB immunoreactive peak that coeluted with synthetic FPB was identified. In contrast, no FPA immunoreactivity was detected. The FPB immunoreactive fractions were then pooled and subjected to amino acid analysis. The fragment released by urokinase was further characterized as FPB by its amino acid composition (Table I).

Effect of inhibitors and an antibody against urokinase on urokinase-mediated FPB release. To exclude the possibility that urokinase-mediated FPB release is the result of a contaminating proteinase, the effect of a variety of inhibitors was investigated (Table II). FPB release is unaffected by hirudin or by a monospecific antibody against thrombin, indicating that thrombin is not responsible for this activity. In addition, $\alpha_{2-}$ antiplasmin and aprotinin have no effect, thereby excluding plasmin as the mediator of urokinase-induced FPB release. In contrast, peptide release is almost completely abolished by PMSF, and by a monospecific antibody against urokinase. These studies thus indicate that urokinase is the serine proteinase responsible for FPB release.

Urokinase-mediated $F P B$ release from $B \beta 1-42$. To further explore the specificity of urokinase for the $B \beta 14$ (Arg)-B $\beta 15$ (Gly) bond on the $\mathrm{NH}_{2}$-terminal region of the $\mathrm{B} \beta$-chain of fibrinogen, the FPB-containing substrate $B \beta 1-42$ was incubated with urokinase. This results in time-dependent decrease in $B \beta 1-42$ immunoreactivity associated with a parallel increase in FPB immunoreactivity (data not shown), indicating that urokinase releases the FPB portion of the molecule. Confirmation of these findings comes from the results of HPLC analysis of this reaction using $B \beta 1-42$, FPB, and $B \beta 15-42$ as internal standards (Fig. 5). Separation of the products of urokinase-mediated proteolysis of $B \beta 1-42$ reveals a decrease in the B $\beta 1-42$ peak associated with the appearance of two new peaks (Fig. 5 B). The single FPB immunoreactive peak coelutes with FPB standard; the other peak represents $B \beta 15-42$.

Kinetics of urokinase-mediated FPB release. The initial rates of LMW urokinase cleavage of the $B \beta 14$ (Arg)-B $\beta 15$ (Gly) bond of fibrinogen were determined by quantifying released FPB. A double reciprocal plot (Fig. 6) obeys MichaelisMenten kinetics with a Michaelis constant $\left(K_{\mathrm{m}}\right)$, of $15.6 \mu \mathrm{M}$, and catalytic rate constant $\left(k_{\text {cat }}\right)$ of $0.016 \mathrm{~s}^{-1}$. The second-order rate constant $k_{\text {cat }} / K_{\mathrm{m}}$, a measure of the catalytic efficiency of the enzyme, is $0.0013 \mu \mathrm{M}^{-1} \mathrm{~s}^{-1}$. In comparison, the reported $K_{\mathrm{m}}$ for LMW urokinase activation of Glu-plasminogen is 2.65 $\mu \mathrm{M}$, while the $k_{\text {cat }}$ and $k_{\text {cat }} / K_{\mathrm{m}}$ are $1.05 \mathrm{~s}^{-1}$ and $0.398 \mu \mathrm{M}^{-1} \mathrm{~s}^{-1}$, respectively (35). The $k_{\text {cat }}$ for LMW urokinase activation of Glu-plasminogen is thus 66-fold higher; the second-order rate constant $\left(k_{\text {cat }} / K_{\mathrm{m}}\right)$ is more than 300 -fold higher than the com- 


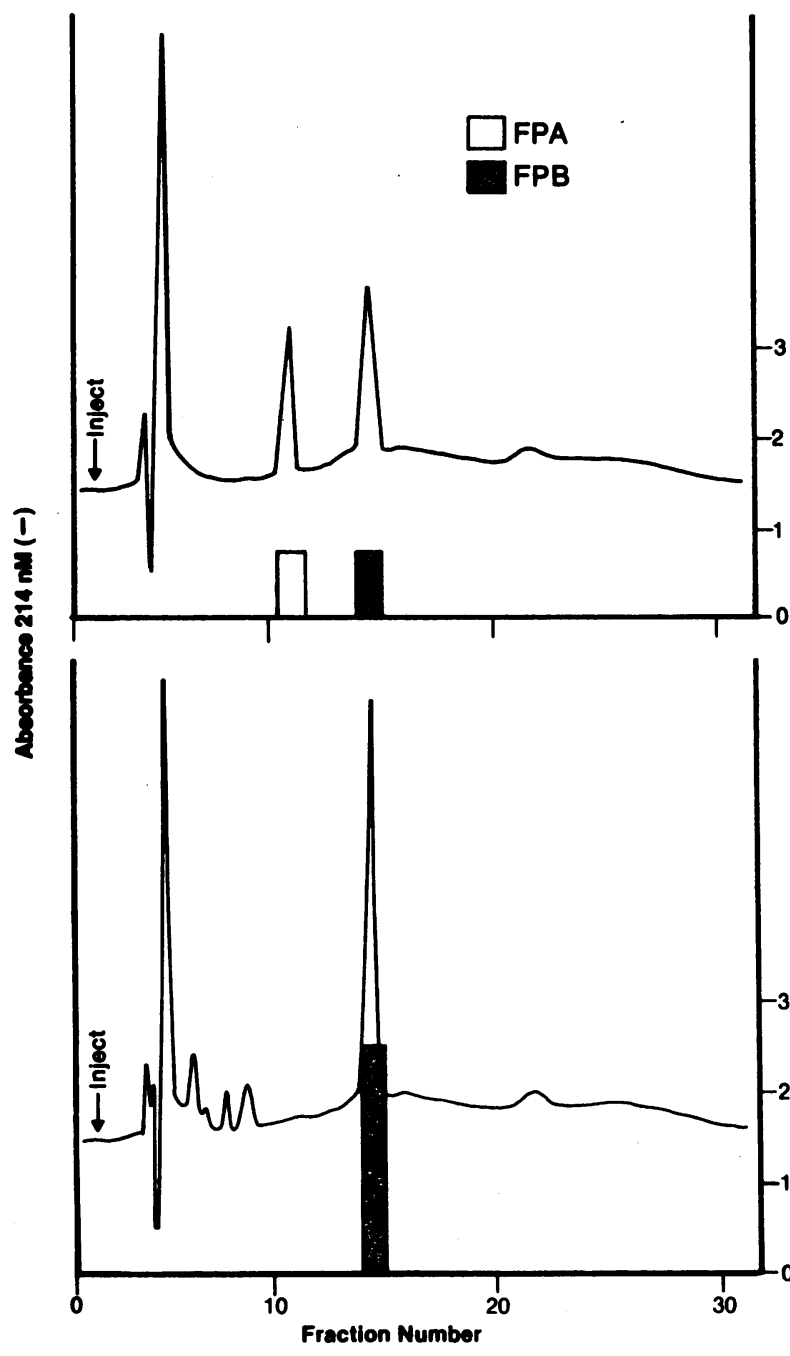

Figure 4. HPLC separation of the products of urokinase digestion of fibrinogen. (Top) $\sim 5 \mu \mathrm{g}$ of FPA and FPB standards were injected onto the column using a flow rate of $1 \mathrm{ml} / \mathrm{min}$. $1-\mathrm{ml}$ fractions were collected, and assayed for FPA and FPB immunoreactivity. (Bottom) Fibrinogen $(2.9 \mu \mathrm{M})$ was incubated with urokinase $(0.5 \mu \mathrm{M})$ for 60 min at $37^{\circ} \mathrm{C}$. The reaction was terminated by the addition of $5 \mathrm{mM}$ PMSF, and undigested fibrinogen was removed by passage of the sample over a $\mathrm{C} 18$ cartridge. Adsorbed peptides were eluted with 3 $\mathrm{ml}$ of $50 \%$ acetonitrile, evaporated to dryness, and dissolved in $0.1 \%$ trifluoroacetic acid. $\sim 50 \mu \mathrm{l}$ of the digestion mixture was injected onto the column using the same flow rate. 1-ml fractions were collected, evaporated to dryness, and then assayed for FPA and FPB immunoreactivity.

parable constants for urokinase cleavage of the $\mathrm{B} \beta 14-15$ bond of fibrinogen.

SDS-PAGE analysis of urokinase-mediated fibrinogenolysis. To determine whether urokinase cleaves other sites on the fibrinogen molecule, the time course of urokinase-mediated fibrinogenolysis also was monitored using SDS-PAGE. As indicated in Fig. 7, there is progressive proteolysis of both the $A \alpha$-chains and $B \beta$-chains of fibrinogen which becomes apparent at $60 \mathrm{~min}$ of incubation and continues for up to $4 \mathrm{~h}$. Concomitant assay of FPB indicates detectable peptide release at $5 \mathrm{~min}$ of incubation. By $\mathbf{4 0} \mathrm{min}$, all of the available FPB (2 $\mathrm{mol} / \mathrm{mol}$ fibrinogen) is released, indicating that cleavage of the
Table I. Amino Acid Composition of the Urokinase-derived Fibrinopeptide

\begin{tabular}{ccc}
\hline Amino acid & Observed & Expected \\
\hline Asp & 2.7 & 3 \\
Ser & 0.9 & 1 \\
Glu* & 3.0 & 3 \\
Gly & 2.1 & 2 \\
Ala & 1.1 & 1 \\
Val & 1.0 & 1 \\
Phe & 1.8 & 2 \\
Arg & 0.9 & 1
\end{tabular}

* One glutamic acid residue represents pyroglutamic acid

$\mathrm{B} \beta 14$ (Arg)- $\mathrm{B} \beta 15$ (Gly) bond is completed before the subsequent proteolysis of the $A \alpha$ - and $B \beta$-chains.

Fibrinogen proteolysis is not the result of contaminating plasmin since degradation is unaffected by aprotinin, and is unaccompanied by $B \beta 1-42$ release. Further, this activity is abolished by a monospecific antibody against urokinase. Finally, no cleavage of the $A \alpha$ - or $B \beta$-chains is evident by SDSPAGE analysis when the fibrinogen is incubated with streptokinase or recombinant t-PA in place of urokinase (data not shown), indicating that proteolysis at these sites is a property unique to urokinase.

Thrombin clotting times of urokinase-treated fibrinogen. Incubation of fibrinogen with LMW urokinase produces progressive prolongation of the thrombin clotting times so that the fibrinogen is unclottable after $90 \mathrm{~min}$ (Fig. 8). To determine whether this reflects impaired polymerization, control fibrinogen was mixed with either unclottable urokinase-treated fibrinogen or saline, and the thrombin clotting times of these mixtures were then compared (Table III). Dilution with urokinase-treated fibrinogen has the same effect on the thrombin clotting time as the addition of an equivalent volume of saline, indicating that the urokinase-treated material does not affect the clottability of normal fibrinogen.

Table II. Effect of Inhibitors and Antibodies against Thrombin and Urokinase on Urokinase-mediated FPB Release

\begin{tabular}{lc}
\hline \multicolumn{1}{c}{ Inhibitor } & FPB \\
\hline & $n M$ \\
None & $155.4 \pm 5.3$ \\
Hirudin $(3 \mathrm{U} / \mathrm{ml})$ & $158.3 \pm 6.2$ \\
Antithrombin $\mathrm{IgG}(10 \mu \mathrm{g} / \mathrm{ml})$ & $161.2 \pm 9.4$ \\
Aprotinin $(100 \mathrm{KIU} / \mathrm{ml})$ & $150.6 \pm 8.7$ \\
$\alpha_{2}$-antiplasmin $(1 \mu \mathrm{M})$ & $148.8 \pm 11.8$ \\
PMSF $(5 \mathrm{mM})$ & $0.9 \pm 0.5$ \\
Anti-urokinase IgG $(15 \mu \mathrm{g} / \mathrm{ml})$ & $1.2 \pm 1.0$ \\
\hline
\end{tabular}

Fibrinogen $(1.8 \mu \mathrm{M})$ was incubated with LMW urokinase (26 nM) for $60 \mathrm{~min}$ at $37^{\circ} \mathrm{C}$ in the presence or absence of the inhibitors or antibodies listed above. At the end of the incubation period, unreacted fibrinogen was precipitated with ethanol, and the ethanol supernatants were assayed for FPB. The results shown represent the mean $\pm S D$ of three separate experiments. 


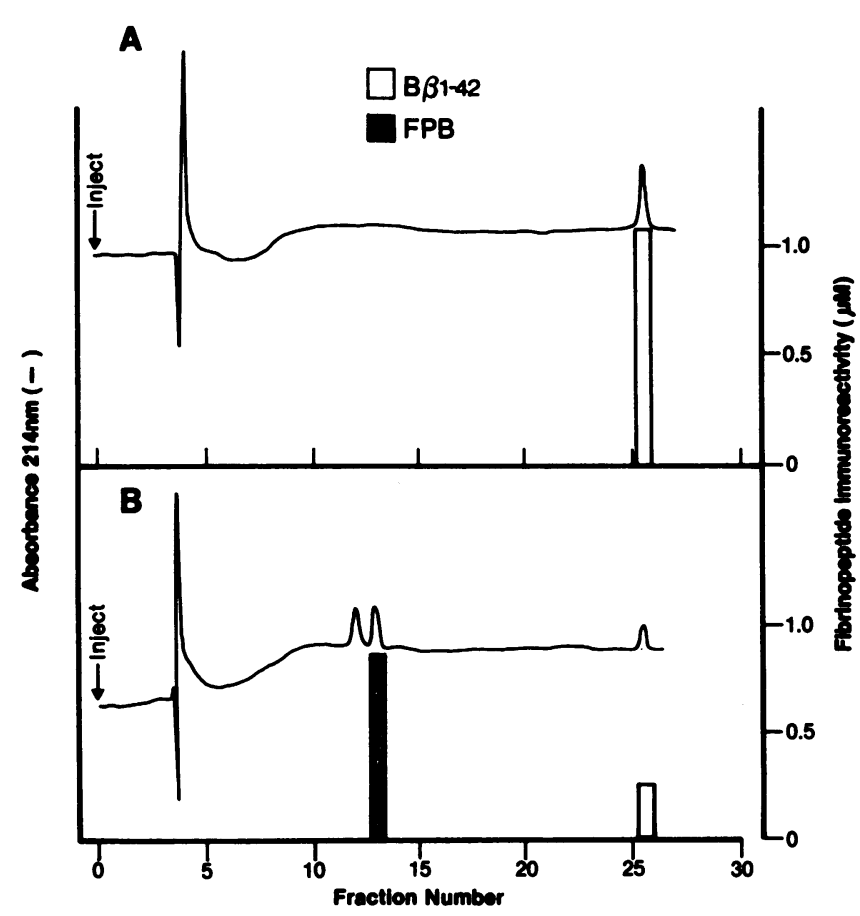

Figure 5. HPLC analysis of urokinase proteolysis of $\mathrm{B} \beta 1-42 .(A) \sim 5$ $\mu \mathrm{g}$ of $\mathrm{B} \beta 1-42$ was injected onto the column using a flow rate of $1 \mathrm{ml} /$ min. 1-ml fractions were collected, evaporated to dryness, and then assayed for B $\beta 1-42$ and FPB immunoreactivity. (B) B $B 1-42(20 \mu \mathrm{g})$ was incubated with urokinase $(2 \mu \mathrm{g})$ for $2 \mathrm{~h}$ at $37^{\circ} \mathrm{C}$. The reaction was terminated by passage of the sample over a $\mathrm{C} 18$ cartridge. Adsorbed peptides were eluted with $3 \mathrm{ml}$ of $50 \%$ acetonitrile, evaporated to dryness, and dissolved in $0.1 \%$ trifluoroacetic acid. 25\% of the starting material was then injected onto the column using the same flow rate. 1-ml fractions were collected, evaporated to dryness, and then assayed for $B \beta 1-42$ and FPB immunoreactivity.

Thrombin-mediated fibrinopeptide release from urokinasetreated fibrinogen. To investigate whether the prolonged thrombin clotting time reflects impaired thrombin-induced

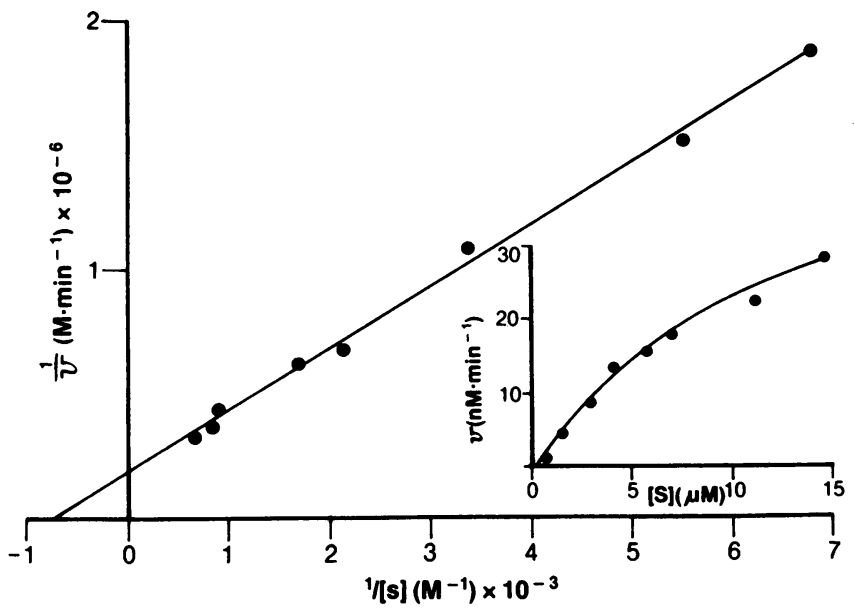

Figure 6. Lineweaver-Burk plot of urokinase-mediated FPB release from fibrinogen. Fibrinogen $(0.74-14.7 \mu \mathrm{M})$ was incubated with LMW urokinase $(500 \mathrm{IU} / \mathrm{ml})$ in Tris-buffered saline, $\mathrm{pH}$ 7.4. (Inset) Analysis of the initial rate of urokinase-mediated FPB release from fibrinogen as a function of the substrate concentration.

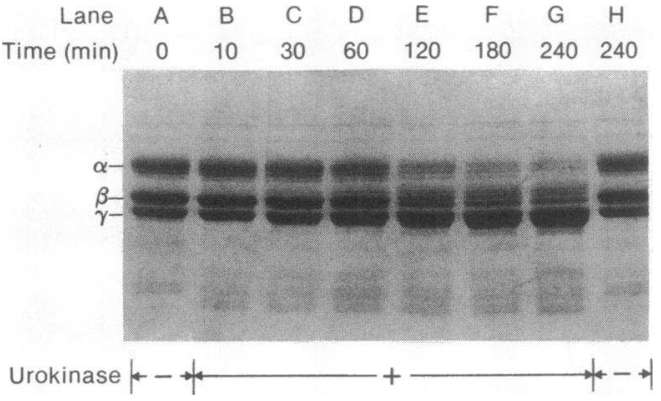

Figure 7. SDS-PAGE analysis of the time course of urokinase-mediated fibrinogenolysis. Fibrinogen (lane $A$ ) was incubated for the times indicated with LMW urokinase (lanes $B-G$ ) or buffer (lane $H$ ) at $37^{\circ} \mathrm{C}$ before heating at $100^{\circ} \mathrm{C}$ for $5 \mathrm{~min}$ with an equal volume of $60 \mathrm{mM}$ Tris- $\mathrm{HCl}$ containing $2 \%$ SDS, $5 \%$ glycerol, $0.001 \%$ bromophenol blue, and 5\% 2-mercaptoethanol. Samples were analyzed on a SDS-polyacrylamide (7.5\%) slab gel that was stained with Coomasie blue. $\sim 4 \mu \mathrm{g}$ of fibrinogen was applied per sample.

FPA release, the time course of thrombin-mediated fibrinopeptide release from urokinase-treated fibrinogen was compared with that from control fibrinogen (Fig. 9). There is no FPB release from the urokinase-treated material, confirming the prior cleavage of this peptide by urokinase. Thrombin effects quantitative release ( $2 \mathrm{~mol} / \mathrm{mol}$ fibrinogen) of FPA from both urokinase-treated and control fibrinogen, indicating that urokinase does not cleave the amino-terminal region of the A $\alpha$-chains of fibrinogen. The rate of thrombin-mediated FPA release from the urokinase-treated material is more rapid than that from the control fibrinogen probably because the prior release of FPB eliminates B $\beta$-chain competition for thrombin binding.

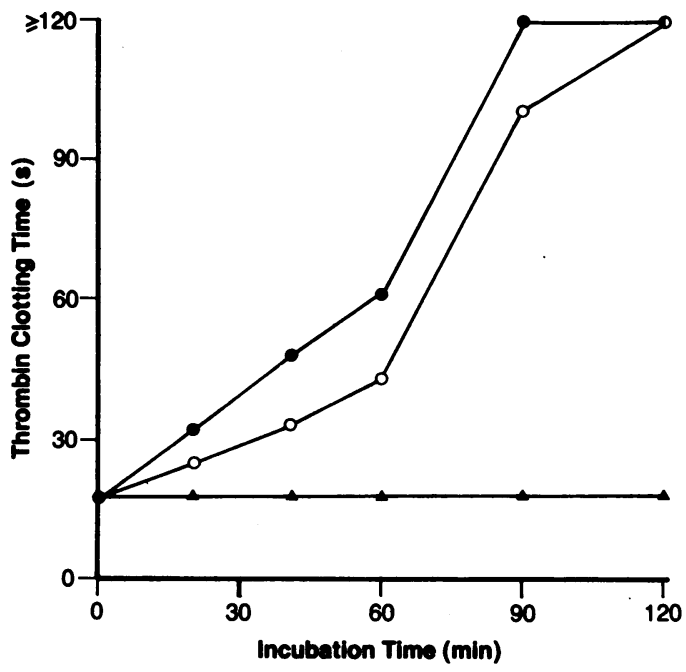

Figure 8 . Thrombin clotting times of fibrinogen incubated with LMW urokinase or buffer. Fibrinogen $(1.2 \mathrm{mg} / \mathrm{ml})$ was incubated at $37^{\circ} \mathrm{C}$ with $0.1 \mu \mathrm{M}(0)$ or $0.2 \mu \mathrm{M}(\bullet) \mathrm{LMW}$ urokinase. In control experiments, the fibrinogen was incubated with buffer $(\Delta)$ in place of enzyme. At the times indicated, aliquots were taken, the samples were incubated with benzamidine-Sepharose as described in Methods, and the thrombin clotting times of the supernatants were then measured. The results shown represent the mean of two separate experiments each done in triplicate. 
Table III. Thrombin Clotting Times of Control Fibrinogen Mixed with Varying Amounts of Urokinase-treated Fibrinogen or Saline

\begin{tabular}{ccc}
\hline & \multicolumn{2}{c}{ Thrombin clotting times } \\
\cline { 2 - 3 } Control fibrinogen & Urokinase-fibrinogen & Saline \\
\hline$\%$ & $s$ & $s$ \\
75 & 25 & 24 \\
50 & 41 & 39 \\
25 & $>120$ & $>120$ \\
\end{tabular}

Control fibrinogen with a thrombin clotting time of $19 \mathrm{~s}$ was mixed with varying amounts of unclottable urokinase-treated fibrinogen (thrombin clotting time $>120 \mathrm{~s}$ ) or saline, and the thrombin clotting time was then determined. The results represent the mean of two separate experiments, each done in triplicate.

Urokinase-mediated generation of FPB and BB1-42 in plasma. To determine whether urokinase-mediated release of FPB occurs in the presence of physiologic concentrations of antiproteinases, increasing concentrations of urokinase were incubated with heparinized plasma (Fig. 10). The plasma levels of $\mathrm{B} \beta 1-42$ were monitored as an index of urokinase activation of plasminogen and subsequent attack on fibrinogen by unopposed plasmin. At the same time, the direct cata-

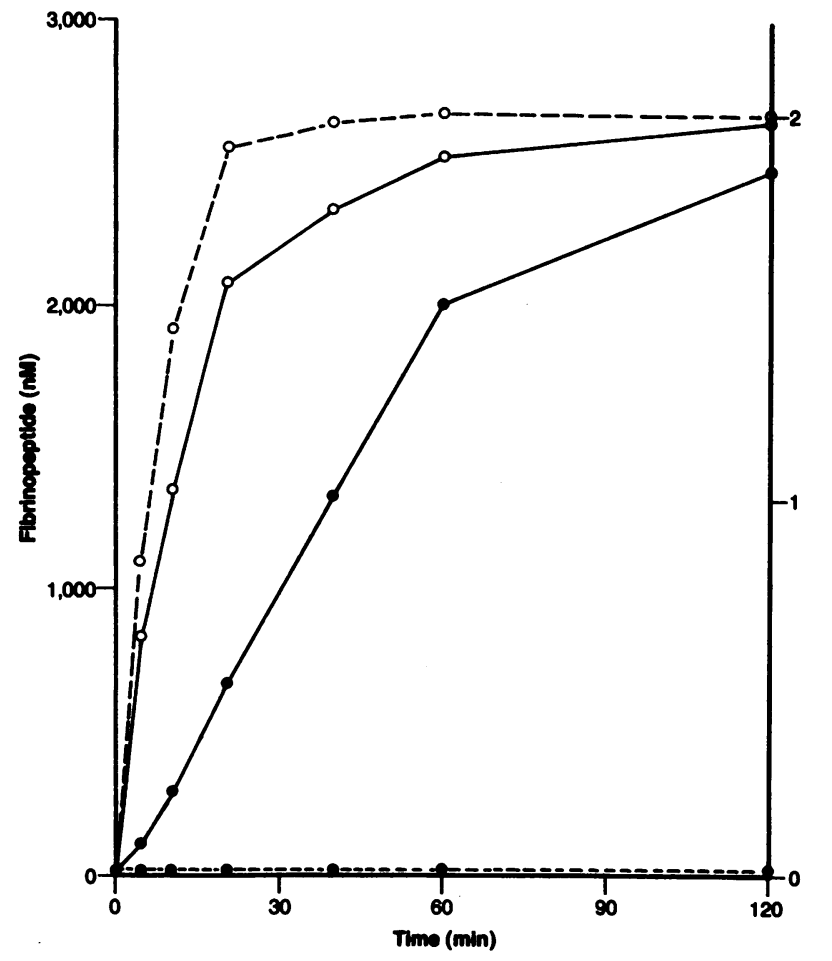

Figure 9. Comparison of thrombin-mediated fibrinopeptide release from urokinase-treated fibrinogen with that from control fibrinogen. Thrombin $(0.02 \mathrm{U} / \mathrm{ml})$ was incubated with urokinase-treated (dashed lines) or control fibrinogen (solid lines) for $2 \mathrm{~h}$ at $37^{\circ} \mathrm{C}$. At the times indicated, aliquots were removed, unreacted fibrinogen was precipitated with ethanol, and the ethanol supernatants were assayed for FPA (o) and FPB (๑).

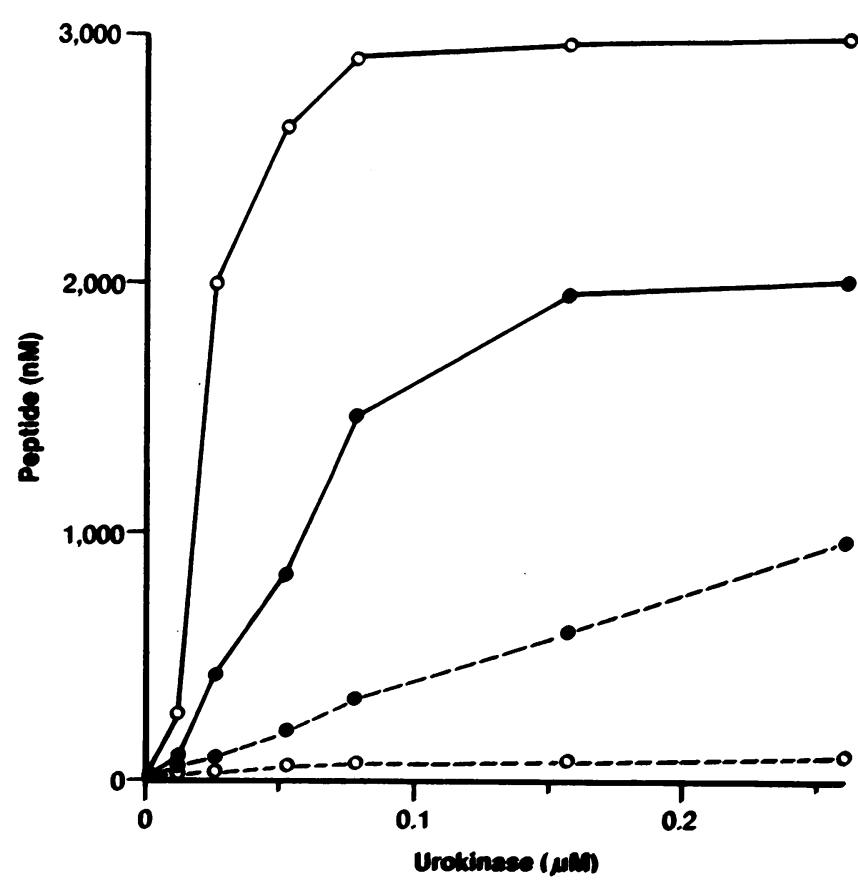

Figure 10. Urokinase-mediated generation of $B \beta 1-42$ and desarginine FPB in heparinized plasma. LMW urokinase ( $26 \mathrm{nM}$ to $0.7 \mu \mathrm{M}$ ) was incubated with heparinized plasma for $60 \mathrm{~min}$ at $37^{\circ} \mathrm{C}$. The reaction was terminated and unreacted fibrinogen was precipitated with ethanol, and the ethanol supernatants were then assayed for $B \beta 1-42$ ( 0 ) and desarginine FPB (๑). The experiment was then repeated in the presence of $1 \mu \mathrm{M} \alpha_{2}$-antiplasmin (dashed lines) and the levels of B $\beta 1-42(0)$ and desarginine FPB (๑) were again determined. The results shown represent the mean of three separate experiments.

lytic activity of urokinase against fibrinogen was assessed by measuring the levels of desarginine FPB, the stable carboxypeptidase-derived metabolite of FPB $(28,29)$.

In plasma, urokinase produces concentration-dependent release of both B $\beta 1-42$ and desarginine FPB (Fig. 10). At each concentration of enzyme, the levels of $B \beta 1-42$ are two- to fourfold higher than those of desarginine FPB. With urokinase concentrations of $0.16 \mu \mathrm{M}$ or higher, the peptide values reach a plateau representing complete cleavage of the amino-terminal regions of the $B \beta$-chains of fibrinogen with quantitative release ( $2 \mathrm{~mol}$ peptide/mol fibrinogen) of either the $\mathrm{B} \beta 1-42$ or the desarginine FPB fragment.

The generation of desarginine FPB by urokinase could be caused either by direct cleavage of FPB from fibrinogen or FPB could be released from the plasmin-derived $B \beta 1-42$ fragment as illustrated in Fig. 5. To determine the relative contribution of each of these pathways, B $\beta 1-42$ release was blocked by the addition of $\alpha_{2}$-antiplasmin (Fig. 10) or aprotinin (data not shown) and desarginine FPB levels were measured. The residual desarginine FPB reflects the direct action of urokinase on fibrinogen, since these inhibitors have minimal effects on urokinase-mediated FPB release from fibrinogen (Table II). In the presence of $\alpha_{2}$-antiplasmin or aprotinin, there remains concentration-dependent release of desarginine FPB, albeit to a much lesser extent, despite almost complete inhibition of B $1-42$ release. These data thus demonstrate that urokinasemediated generation of desarginine FPB in plasma is the result of hydrolysis of both fibrinogen, and the plasmin-derived B $\beta 1-42$ fragment. 


\section{Discussion}

This study demonstrates that urokinase, like t-PA (20), also has direct catalytic activity against fibrinogen. In contrast to t-PA, however, urokinase only releases FPB, and also cleaves the $A \alpha$-chains of fibrinogen. On a mole for mole basis, urokinase releases considerably more FPB than does t-PA. Thus, quantitative FPB release ( $2 \mathrm{~mol} \mathrm{FPB} / \mathrm{mol}$ fibrinogen) is effected by urokinase concentrations of $1 \mu \mathrm{M}$ or more (Fig. 2), whereas our previous studies demonstrated that similar concentrations of t-PA release $<10 \%$ of the available FPB (20).

Confirmation that the increase in FPB immunoreactivity that occurs when urokinase is incubated with fibrinogen reflects release of the free peptide (Figs. 1 and 2) comes from the HPLC demonstration that the FPB immunoreactive peak in the digestion mixture coelutes with native or synthetic FPB (Fig. 3). This material was further characterized as FPB by its amino acid composition (Table I).

The pattern of urokinase-mediated fibrinopeptide release is different from that produced by thrombin, since thrombin releases both FPA and FPB from fibrinogen $(27,34)$. Furthermore, release of FPB by urokinase occurs in the presence of the thrombin inhibitors, heparin (Fig. 10) and hirudin (Table II), and is unaffected by a monospecific antibody against thrombin (Table II). Contaminating plasmin is not responsible for FPB release by urokinase because $\alpha_{2}$-antiplasmin and aprotinin have no effect on this activity (Table II). In addition, plasmin releases $B \beta 1-42$ from fibrinogen $(30,36)$, rather than FPB, and no $B \beta 1-42$ was detected in the digestion mixture.

That FPB release is due to the direct catalytic activity of urokinase is illustrated by the virtually complete inhibition of this reaction with a monospecific antibody against urokinase (Table II). Further, urokinase releases FPB from the FPB-containing substrate $B \beta 1-42$ (Fig. 5), thereby confirming its specificity for the $B \beta 14-15$ bond. Finally, FPB release is effected by both HMW and LMW urokinase (Fig. 3), indicating that FPB release is a property of both forms of two-chain urokinase. For equivalent amidolytic activity, however, HMW urokinase has approximately twofold greater FPB releasing activity than the LMW species. In contrast, prourokinase does not release FPB from fibrinogen, consistent with previous reports that prourokinase is a zymogen that has little or no intrinsic enzymatic activity until activated to urokinase (16-18).

To determine whether urokinase cleaves other sites on the fibrinogen molecule, the time-course of urokinase-mediated fibrinogenolysis also was monitored by SDS-PAGE (Fig. 7). Urokinase produces progressive proteolysis of the $\mathrm{A} \alpha$ - and $\mathrm{B} \beta$-chains which becomes apparent at $60 \mathrm{~min}$ of incubation, and continues over the subsequent $4 \mathrm{~h}$. In contrast, the release of FPB is completed by $40 \mathrm{~min}$, indicating that the $B \beta 14$ (Arg)-B $\beta 15$ (Gly) bond is the preferred site of urokinase cleavage.

Urokinase cleavage of fibrinogen results in progressive prolongation of the thrombin clotting time (Fig. 8) so that the fibrinogen becomes unclottable by $90 \mathrm{~min}$. This is not the result of impaired FPA release since thrombin induces quantitative ( $2 \mathrm{~mol} / \mathrm{mol}$ fibrinogen) release of FPA from urokinasetreated fibrinogen (Fig. 9). The decrease in clottability appears to coincide with the subsequent proteolysis of the $A \alpha$ - and $B \beta$-chains. The most likely explanation for the prolonged clotting times, therefore, is that progressive urokinase-mediated proteolysis either cleaves or alters the conformation of a critical polymerization domain on the fibrinogen molecule.

The finding that urokinase has direct catalytic activity against fibrinogen is consistent with recent evidence that this enzyme has specificity for substrates other than plasminogen. Quigley et al. (37), demonstrated that urokinase degrades fibronectin under plasminogen-free conditions and releases several high molecular weight cleavage products. More recently, urokinase also has been shown to cleave and activate diphtheria toxin (38).

Comparison of the kinetic parameters for urokinase cleavage of the $B \beta 14$ (Arg)-B $\beta 15$ (Gly) bond of fibrinogen with those reported for urokinase activation of Glu-plasminogen indicate that Glu-plasminogen is the preferred substrate in buffer systems. Despite these observations however, the incubation of urokinase with heparinized plasma results in the generation of both the plasmin-derived $B \beta 1-42$ fragment and desarginine FPB (Fig. 10), and the levels of $B \beta 1-42$ are only two to fourfold higher than those of desarginine FPB. There are two explanations for the higher than expected levels of desarginine FPB in plasma. First, $\alpha_{2}$-antiplasmin inhibits plasmin-mediated $B \beta 1-42$ release without affecting the direct action of urokinase on fibrinogen (Table II). Secondly, the FPB that is generated in plasma is not only derived from direct urokinase cleavage of fibrinogen but also is a product of secondary urokinase-mediated attack on the plasmin-derived $\mathrm{B} \beta 1-42$ fragment.

The present study indicates that urokinase has direct catalytic activity against fibrinogen that results in release of FPB, and cleavage of the carboxy terminals of the A $\alpha$-chains. Both of these effects may be physiologically relevant. Recent evidence indicates that a wide variety of mammalian cells synthesize u-PA (39-41). Secreted or circulating u-PA binds to receptors found on inflammatory cells $(42,43)$. With the accumulation of these cells in thrombi or at extravascular sites of inflammation or tissue repair, the local concentrations of $u-P A$ may reach those used in this study. Surface-bound enzyme is protected from circulating inhibitors $(41,44)$. In addition, the close apposition of u-PA bearing cells to fibrinogen may prevent access of antiproteinases to enzymes released at the cellsubstrate interface (45-49), thereby producing a protected environment in which urokinase can degrade fibrinogen. Through localized release of FPB, a potent chemoattractant for neutrophils $(50,51)$ and fibroblasts $(51)$, urokinase has the potential to recruit more inflammatory and/or mesenchymal cells which can then amplify the inflammatory process. In addition, proteolysis of the $A \alpha$-chains of fibrinogen renders the molecule less clottable by thrombin and so has the potential to modulate thrombogenesis at sites of vessel injury.

\section{Acknowledgments}

The authors wish to thank Drs. J. Henkin, Abbott Laboratories, North Chicago, IL, and J. Hirsh, McMaster University and Hamilton Civic Hospitals Research Centre, Hamilton, Ontario, for their excellent advice and encouragement and S. Crnic, McMaster University and Henderson General Hospital, Hamilton, Ontario, for preparing the manuscript.

This investigation was supported by grants from the Medical Research Council of Canada and the Ontario Heart and Stroke Foundation. Dr. Weitz is a Scholar of the Heart and Stroke Foundation of Ontario. 


\section{References}

1. Hoylaerts, M., D. C. Rijken, H. R. Lijnen, and D. Collen. 1982. Kinetics of the activation of plasminogen by human tissue plasminogen activator: role of fibrin. J. Biol. Chem. 257:2912-2919.

2. Ranby, M. 1982. Studies on the kinetics of plasminogen activation by tissue plasminogen activator. Biochim. Biophys. Acta. 704:461-469.

3. Blasi, F. 1988. Surface receptors for urokinase plasminogen activator. Fibrinolysis. 2:73-84.

4. Blasi, F., J.-D. Vassali, and K. Dano. 1987. Urokinase-type plasminogen activator: proenzyme, receptors and inhibitors. J. Cell Biol. 104:801-804.

5. Vassali, J.-D., D. Baccino, and D. Belin. 1985. A cellular binding site for the $M 55,000$ form of the human plasminogen activator, urokinase. J. Cell Biol. 100:86-92.

6. Stoppelli, M. P., A. Corti, A. Soffientini, G. Cassani, F. Blasi, and R. K. Assoian. 1985. Differentiation-enhanced binding of the aminoterminal fragment of human urokinase plasminogen activator to a specific receptor on U937 monocytes. Proc. Natl. Acad. Sci. USA. 82:4939-4943.

7. Blasi, F., M. P. Stoppelli, and M. V. Cubellis. 1986. The receptor for urokinase-plasminogen activator. J. Cell. Biochem. 32:179-186.

8. Bajpai, A., and J. B. Baker. 1985. Urokinase binding sites on human foreskin cells: evidence for occupancy with endogenous urokinase. Biochem. Biophys. Res. Commun. 133:994-1000.

9. Keski-Oja, J., and A. Veheri. 1982. The cellular target for the plasminogen activator, urokinase, in human fibroblasts: 66,000 -dalton protein. Biochim. Biophys. Acta. 720:141-146.

10. Del Rosso, M., G. Dini, and G. Fibbi. 1985. Receptors for plasminogen activator, urokinase, in normal and Rous sarcoma virustransformed mouse fibroblasts. Cancer Res. 45:630-636.

11. Stoppelli, M. P., C. Tacchetti, M. V. Cubellis, A. Corti, V. J. Hearing, G. Cassani, E. Appella, and F. Blasi. 1986. Autocrine saturation of pro-urokinase receptors on human A432 cells. Cell. 45:675684.

12. Holmes, W. E., D. Pennica, M. Blaber, M. W. Rey, W. A. Gunzler, G. J. Steffens, and H. L. Heyneker. 1985. Cloning and expression of the gene for pro-urokinase in Escherichia coli. Biotechniques. 3:923-929.

13. Gunzler, W. A., G. J. Steffens, F. Otting, S. M. Kim, E. Frankus, and L. Flohe. 1982. The primary structure of high molecular mass urokinase from human urine: the complete amino acid sequence of the A chain. Hoppe Seyler's Z. Physiol. Chem. 363:1155-1165.

14. Ichinose, A., W. Kisiel, and K. Fukikawa. 1985. Proteolytic activation of tissue plasminogen activator by plasmin and tissue enzymes. FEBS (Fed. Eur. Biochem. Soc.) Lett. 175:412-418.

15. Rijken, D. C., M. Hoylaerts, and D. Collen. 1982. Fibrinolytic properties of one-chain and two-chain human extrinsic (tissue-type) plasminogen activator. J. Biol. Chem. 257:2920-2925.

16. Wun, T. C., L. Ossowski, and E. Reich. 1982. A proenzyme form of urokinase. J. Biol. Chem. 257:7262-7268.

17. Ellis, V., M. F. Scully, and V. V. Kakkar. 1987. Plasminogen activation by single-chain urokinase in functional isolation. J. Biol. Chem. 262:14998-15003.

18. Petersen, L. C., L. R. Lund, L. S. Nielsen, K. Dano, and L. Skriver. 1988. One-chain urokinase-type plasminogen activator from human sarcoma cells is a proenzyme with little or no intrinsic activity. J. Biol. Chem. 263:11189-11195.

19. Steffens, G. J., Gunzler, W. A., F. Otting, E. Frankus, and L. Flohe. 1982. The complete amino acid sequence of low molecular mass urokinase from human urine. Hoppe Seyler's Z. Physiol. Chem. 363:1043-1058.

20. Weitz, J. I., M. K. Cruickshank, B. Thong, B. Leslie, M. N. Levine, J. Ginsberg, and T. Eckhardt. 1988. Human tissue-type plasminogen activator releases fibrinopeptides $\mathrm{A}$ and $\mathrm{B}$ from fibrinogen. $J$. Clin. Invest. 82:1700-1707.
21. Skogen, W. F., and G. D. Wilner. 1986. A simple one-step HPLC procedure for the purification of the $\mathrm{NH}_{2}$-terminal plasmin-derived B $\beta 1-42$ peptide of human fibrinogen. Thromb. Res. 41:161-166.

22. Holmberg, L., B. Bladh, and B. Astedt. 1976. Purification of urokinase by affinity chromatography. Biochim. Biophys. Acta. 445:215-222.

23. Chibber, B. A. K., D. G. Deutsch, and E. T. Mertz. 1974. Plasminogen. Methods Enzymol. 34:424-432.

24. Nossel, H. L., I. Yudelman, R. E. Canfield, V. P. Butler Jr., K. Spanondis, G. D. Wilner, and G. D. Qureshi. 1974. Measurement of fibrinopeptide A in human blood. J. Clin. Invest. 54:43-53.

25. Canfield, R. E., J. Dean, H. L. Nossel, V. P. Butler Jr. 1976. Reactivity of fibrinogen and fibrinopeptide A containing fragments with antisera to fibrinopeptide A. Biochemistry. 15:1203-1209.

26. Wilner, G. D., H. L. Nossel, R. E. Canfield, and V. P. Butler Jr. 1976. Immunochemical studies of human fibrinopeptide A using synthetic peptide homologues. Biochemistry. 15:1209-1213.

27. Bilizekian, S. B., H. L. Nossel, V. P. Butler, Jr., and R. E. Canfield. 1975. Radioimmunoassay of fibrinopeptide B and kinetics of fibrinopeptide cleavage by different enzymes. J. Clin. Invest. 56:438445.

28. LaGamma, K. S., and H. L. Nossel. 1978. The stability of fibrinopeptide B immunoreactivity in blood. Thromb. Res. 12:447454.

29. Eckhardt, T., H. L. Nossel, A. Hurlet-Jensen, K. S. LaGamma, J. Owen, and M. Auerbach. 1981. Measurement of desarginine fibrinopeptide B in human blood. J. Clin. Invest. 67:809-816.

30. Weitz, J. I., J. A. Koehn, R. E. Canfield, S. L. Landman, and R. Friedman. 1986. Development of a radioimmunoassay for the fibrinogen-derived fragment B $\beta 1-42$. Blood. 67:1014-1022.

31. Laemmli, U. K. 1970. Cleavage of structural proteins during the assembly of the head of bacteriophage T4. Nature (Lond.). 227:680-685.

32. Spackman, D. H., W. H. Stein, and S. Moore. 1958. Automated recording apparatus for use in the chromatography of amino acids. Anal. Chem. 30:1190-1206.

33. Lowry, O. H., N. J. Rosebrough, A. L. Farr, and R. J. Randall. 1951. Protein measurement with the Folin phenol reagent. J. Biol. Chem. 193:265-275.

34. Blomback, B., B. Hessel, D. Hogg, and L. Therkildsen. 1978. A two-step fibrinogen-fibrin transition in blood coagulation. Nature (Lond.). 275:501-505.

35. Wohl, R. C., L. Summaria, and K. Robbins. 1980. Kinetics of activation of human plasminogen by different activator species at $\mathrm{pH}$ 7.4 and $37^{\circ} \mathrm{C}$. J. Biol. Chem. 255:2005-2013.

36. Koehn, J. A., A. Hurlet-Jensen, H. L. Nossel, and R. E. Canfield. 1983. Sequence of plasmin proteolysis at the $\mathrm{NH}_{2}$-terminus of the B $\beta$-chain of human fibrinogen. Anal. Biochem. 133:502-510.

37. Quigley, J. P., L. I. Gold, R. Schwimmer, and L. M. Sullivan. 1987. Limited cleavage of cellular fibronectin by plasminogen activator purified from transformed cells. Proc. Natl. Acad. Sci. USA. 84:2776-2780.

38. Cieplak, W., C. Hasemann, and L. Eidels. 1988. Specific cleavage of diphtheria toxin by human urokinase. Biochem. Biophys. Res. Commun. 157:747-754.

39. Chapman, H. A., F. Vavrin, and J. B. Hibbs, Jr. 1982. Macrophage fibrinolytic activity; identification of the pathways of plasmin formation by intact cells and of a plasminogen activator inhibitor. Cell. 28:653-662.

40. Vassalli, J. D., J. M. Dayer, A. Wohlend, and D. Belin. 1984. Concomitant secretion of prourokinase and of a plasminogen activator-specific inhibitor by cultured human monocytes-macrophages. $J$. Exp. Med. 159:1653-1668.

41. Saksela, O., T. Hovi, and A. Vaheri. 1985. Urokinase-type plasminogen activator and its inhibitor secreted by cultured human monocytes-macrophages. J. Cell. Physiol. 122:125-132.

42. Cubellis, M. V., M. L. Nolli, G. Cassani, and F. Blasi. 1981. 
Binding of single chain prourokinase to the urokinase receptor of U937 cells. J. Biol. Chem. 261:15819-15822.

43. Miles, L. A., and E. F. Plow. 1987. Receptor mediated binding of the fibrinolytic components, plasminogen and urokinase to peripheral blood cells. Thromb. Haemostasis. 58:936-942.

44. Stephens, R. W., J. Pollanen, H. Tapiovaara, K.-C. Leung, P.-S. Sim, E.-M. Salonen, E. Ronne, N. Behrendt, K. Dano, and A. Vaheri. 1989. Activation of pro-urokinase and plasminogen on human sarcoma cells: a proteolytic system with surface-bound reactants. J. Cell. Biol. 108:1987-1995.

45. Wright, S. D., and S. Silverstein. 1984. Phagocytosing macrophages exclude proteins from the zones of contact with targets. Nature (Lond.). 309:359-361.

46. Chapman, H. A., Jr., and O. L. Stone. 1984. Comparison of live human neutrophil and alveolar macrophage elastolytic activity in vitro. J. Clin. Invest. 74:1693-1700.

47. Campbell, E. J., R. M. Senior, J. A. McDonald, and D. L. Cox.
1982. Proteolysis by neutrophils. Relative importance of cell-substrate contact and oxidative inactivation of proteinase inhibitors in vitro. $J$. Clin. Invest. 70:845-852.

48. Weitz, J. I., A. J. Huang, S. L. Landman, S. C. Nicholson, and S. C. Silverstein. 1987. Elastase-mediated fibrinogenolysis by chemoattractant-stimulated neutrophils occurs in the presence of physiologic concentrations of antiproteinases. J. Exp. Med. 166:1836-1850.

49. Wright, S. D., J. I. Weitz, A. J. Huang, S. M. Levin, S. C. Silverstein, and J. D. Loike. 1988. Complement receptor type three (CD1 1b/CD18) of human polymorphonuclear leukocytes recognizes fibrinogen. Proc. Natl. Acad. Sci. USA. 85:7734-7738.

50. Kay, A. B., D. S. Pepper, and R. McKenzie. 1974. The identification of fibrinopeptide $B$ as a chemotactic agent derived from human fibrinogen. Br. J. Haematol. 27:669-677.

51. Senior, R. M., W. F. Skogen, G. L. Griffin, and G. D. Wilner. 1986. Effects of fibrinogen derivatives upon the inflammatory response. Studies with human fibrinopeptide B. J. Clin. Invest. 77:1014-1019. 